\title{
Shakespeare's Penknife: Grafting and Seedless Generation in the Procreation Sonnets
}

\author{
VIN NARDIZZI
}

University of British Columbia

Cet essai remet dans son contexte la figure de la greffe qu'utilise Shakespeare dans ses « sonnets de procréation 》 (numéro 1-17) par l'examen de la présentation de cette technique horticole dans la littérature de jardinage des seizième et dix-septièmes siècles. On y argue que le personnage du sonnet 15 se réfère à cette littérature, se terminant sur le vers «I engraft you new », visualisant la greffe horticole autant comme une technique d'écriture que comme une forme analogue à la procréation humaine. En tant qu'écriture, la greffe permet à l'orateur de se hisser au niveau des héritiers et de la poésie, puisque le canif est indispensable autant au poète qu'au jardinier, respectivement pour préparer une plume et une greffe. Toutefois, en tant qu'analogue de la procréation humaine, la greffe ne procède pas par semis ou par mélange des semences. Au lieu de cela, elle constitue une forme de génération ne nécessitant pas de semences, et de ce fait évoque le potentiel de la greffe comme reproduction travestie dans les Sonnets de Shakespeare.

$\mathrm{A}_{\text {pronouncement to the beautiful young man: "I engraft you new" (1.14). }{ }^{1} \text { In doing }}^{\text {the close of Sonnet 15, the speaker of Shakespeare's Sonnets makes a spectacular }}$ so, he links procreation to poetry-making through an image of plant grafting. As Bruce R. Smith observes, Sonnet 15 not only "sets up" the figures of generation in Sonnet 16 ("maiden gardens" [1.6] and "living flowers" [1.7]) but also embeds a pun on graphein (Greek: "to write"). "Despite the pun," Smith continues, "sonnets 15 and 16 keep the two senses of 'engraft' entirely separate: the poet creates, the friend procreates." Such balanced prose aims to repeat a strategy that Smith claims for the speaker: "The persona himself keeps his distance from sexual desire" throughout the sub-sequence of poems traditionally dubbed the procreation sonnets. ${ }^{2}$ The practice of plant grafting, however, was regarded in sixteenth- and early seventeenth-century English gardening manuals as both an analogue to procreation and a form of writing. Such an understanding of "engraft," I argue, organizes the discourses of generation and genealogy in the sub-sequence, where the speaker shifts from urging the young man to procreate to offering his own verse as a replacement for the male heir the young man has declined to sire. It operates as a hinge in Sonnet 15, joining procreation 
and poetry-making conceptually and materially: as we shall see, both grafters and poets in Renaissance England employed a penknife to generate new flowers.

Smith's assertion that Sonnet 15 does not activate the full associative nexus of plant grafting stems, I think, from his greater interest in presenting the speaker's "real subject" - the "homosexual desire" inaugurally expressed in the "master mistress" (1.2) conceit of Sonnet 20.3 Attention to the "imaginative vocabulary" of this desire, as Smith explains, revises and supplements a Foucauldian tradition of writing a history of homosexuality that privileges the cursory codifications found in legal, medical, and moral discourses and which suspects the evidence that literature affords. ${ }^{4}$ Since the early 1990 , when Smith published his important study, the homoerotic re-deployment of classical texts, as well as affectionate gestures recorded between men in letters and correspondence, for example, have come to engage Renaissance scholars as much as have English court records and "hard-word" entries for buggers, catamites, ganymedes, ingles, and sodomites. ${ }^{5}$ The writing of these histories - and such writing, it bears emphasizing, has overwhelmingly prioritized male homosexuality-has also had the effect of spurring scholars to re-assess and to study other instantiations of desire and sexuality, normative and otherwise, in Renaissance England. For instance, it is now a critical commonplace that "lesbian" desire was not, as had been hitherto supposed, always and fundamentally elegiac, (in)significant, and invisible in the archives; we have a vocabulary for describing female homoeroticism in Renaissance letters and for theorizing the implications of its manifold representations. ${ }^{6}$ Scholarship has likewise challenged entrenched assumptions about the obviousness and transparency of heterosexual congress and desire, detailing variously queer configurations of such desire and practice that unravel simple equations of heterosexuality with marriage and procreative sex. ${ }^{7}$ Indeed, Rebecca Ann Bach has boldly advanced the project of writing a history of Renaissance heterosexuality by claiming that heterosexuality as we know it and as we experience its effects in twenty-first-century culture did not yet exist in Shakespeare's England. ${ }^{8}$ There were, of course, marriage and heterosexual sex, but these occurred in a world that, in Laurie Shannon's fine phrase, was nonetheless thoroughly homonormative. ${ }^{9}$

My essay contributes to this larger project of re-thinking heterosexuality in Renaissance England, especially its relation to "homosexual desire" and male sociability, by insisting, in the first instance, on the fusion of that which Smith's reading of Sonnet 15 separates out rhetorically (procreation and poetic creation). Addressing both the prescriptive discourse of Renaissance "how-to" books for gardening and the imaginative vocabulary of Shakespeare's plays and poems, it sets 
about a philological inquiry into plant grafting to make a theoretical point about concepts of generation in Renaissance England. For it proposes "graft" as a keyword for a kind of creation that confounds a distinction between the two models of generation pervading critical discussions of these sonnets and of Renaissance versifying more generally_reproduction and male parthenogenesis. Unlike these models, both of which had yet to be named in Shakespeare's England, plant grafting does not produce more fruit (or multi-hued blooms) through the implanting or development of seed. Instead, it is a form of generation in which a gardener pares a scion with his (or her) knife so that it will fit into an incision made into a stock plant; this scion, the third-party gardener hopes, will successfully cleave with the stock plant, and new fruit or blooms will spring forth from the supervised conjunction of plant sap. Plant grafting differs from "seeded" botanical generation in that its procedures are sexualized in gardening guides ${ }^{10}$ : indeed, as we shall observe, prescriptions for grafting sometimes designate this growth as "multiplication," explicating its seedless and preternatural generative processes through an allusion to the Old Testament injunction to "increase and multiply." 11 The speaker of Sonnet 15, then, offers the beautiful young man precisely this seedless, discursively procreative genealogical option when he promises to graft (for) him in verse. But by disarticulating the imperative of genealogical succession from the "seeded" generational act of human procreation, the gardener-poet of these sonnets also tends to the plant-like body of the beautiful young man queerly.

\section{"Men As Plants Increase": Grafting and the Verbs of Biblical Genealogy}

Shakespeare famously enlists plant grafting to stage an instance of the perennial art / nature debate in the Bohemian countryside of The Winter's Tale. At the sheepshearing festivities, Perdita avers that she will not allow "streaked gillyvors" or grafted carnations into her garden because, in the flowers' "piedness," she detects "an art which ... shares/ With great creating nature" (4.4.82, 87-88). ${ }^{12}$ Polixenes, the disguised Bohemian monarch, counters Perdita's declamation against "nature's bastards" (4.4.83), arguing instead that grafting "is an art/ Which does mend nature-change it rather; but/ The art itself is nature" (4.4.95-97). Just before he articulates this oxymoronic conclusion about the artificial nature of plant grafting, a conclusion Perdita will ratify (4.4.97), ${ }^{13}$ Polixenes describes how to graft:

You see, sweet maid, we marry

A gentler scion to the wildest stock, 
And make conceive a bark of baser kind

By bud of nobler race. (4.4.92-95)

Rebecca Bushnell has recently reminded us that these instructions for grafting are suffused with adjectival markers of civility and social rank-"gentler," "wildest," "baser," and "nobler." She also reminds us that the mixing of rank which grafting is said to effect undercuts Polixenes' ringing endorsement, for, despite the high regard he claims to have for grafting, this masquerading monarch would never assent to the application of its social logics to his realm. ${ }^{14}$ Polixenes, after all, attends the sheep-shearing to spy on his son Florizel and to put a stop to his romance with the shepherdess. Indeed, soon after the resolution of their art / nature debate, Florizel proposes a marriage "contract" to Perdita (4.4.404), and Polixenes, now no longer disguised, reviles his "sceptre's heir" for inappropriately "affect[ing] a sheep-hook" (4.4.407-408). He even goes so far as to threaten to "bar" his son "from succession" should Florizel persist in his desire for Perdita (4.4.417). (At this point in the play, Polixenes does not know that the shepherdess is Perdita, the long-lost Sicilian princess, and so does not yet comprehend the aptness of this match.) Further elaborating the consequence of his son's impropriety, Polixenes invokes an adjectival marker that he has associated with grafting and, in doing so, implicitly reconfigures his earlier position on this practice: Florizel renders himself "too base/ To be acknowledged" by seeking Perdita's hand in marriage (4.4.406-407, emphasis mine). Encoded in this angry response to the heir apparent's near misstep, the act of grafting, here a figurative counterpart to the gardening practice, resembles social degeneracy rather than engineered fruitfulness. Although Perdita and Polixenes are initially at loggerheads, they both ultimately articulate a conservative stance on the matter of plant grafting. The shepherdess banishes nature's artifice from her garden (4.4.99-100), and the monarch forcefully attempts to ward off the ruinous effect of a socially disadvantageous graft on his lineage.

Thus rich in dramatic irony and social allegory, the iteration of the art / nature debate in The Winter's Tale also proves curiously elliptical. It is replete with colourful references to flowers ("carnations and streaked gillyvors" [82], "nature's bastards" [83], and "slips" [85, 100]) and to gardening implements ("dibble" or trowel [100]). It lists the botanical necessaries for gardening and grafting ("scion" and "stock" [93] and "bud" [95]). And it even goes so far as to incorporate instructions for grafting (92-95). The audience knows full well that Perdita and Polixenes know full well that they are disputing the merits of grafting, yet the debaters nowhere name grafting or its variants; they invariably speak the nouns "art" and, once, "nature" in its stead ( 87 , $90,91,95,97)$. The verbs Polixenes uses in his description of how to graft—-marry" 
(92) and "make conceive" (94) — register, at first glance, as flowery euphemisms for the work-a-day labours of the gardener. They certainly anticipate the heated encounter father will have with son about the proposed marriage to Perdita, and they may even encrypt the particular form of genealogical disrepute that marriage to a low-born shepherdess would bring upon the Bohemian dynasty-a debased, because only partial, aristocratic heir, a bastard of sorts. It is, however, too simplistic to regard these verbs for grafting as merely euphemistic and proleptic. It is also apt to view them as participating, in a witty fashion, in the literature of Renaissance gardening, where grafting shares vocabularies, specifically verbs, with the $u r$-model of Judeo-Christian genealogy and conjugal procreation- "increase and multiply." David Glimp has recently employed this phrase to name his study of governmentality and cultural reproduction in the milieu of Renaissance humanism. ${ }^{15}$ Here I highlight how writers of this gardening literature use "increase and multiply," an axiom which, as we shall see, was aligned with higher order creatures in Genesis, to explicate the process of grafting flowers, plants, and fruit-blooming trees, exemplifying the habit of premodern thought that Foucault, in The Order of Things, dubs "resemblance." In this literature, then, a seed-based paradigm of human procreation and animal generation was invoked to explain the seedless botanies of plant grafting. ${ }^{16}$

Members of Shakespeare's audience familiar with the format of sixteenth-and early seventeenth-century guides to gardening might have recognized that, when Polixenes articulates a procedure for grafting (92-95), he echoes the cadences of these early English "how-to" books. ${ }^{17}$ Generically related to continental books of secrets and compiled from ancient and continental sources about agriculture, such guidebooks, and especially those sections in them devoted to grafting, aimed to whet the buyer / would-be gardener's appetite for horticultural novelty. ${ }^{18}$ Sections on grafting proffer tips for making single-hued flowers multi-coloured (the pied carnations Perdita dismisses) and, even more deliciously, for causing fruit to have a different flavour altogether. Like Polixenes' authoritatively brief instructions for "mak[ing]" fruitfulness, advice in these guidebooks often reads like a recipe. Consider, for instance, these directions for retarding and speeding up the ripening time of mulberries, which Leonard Mascall includes in A booke of the Arte and maner, howe to plant and graffe all sortes of trees ... (1572): "For to haue franck or ripe Mulberies very soone, ye shall graffe them vpon a rathe [early blooming] Peare tree, and vpon the Gosebery tree, and to haue [them] very late and to endure vnto Alhallowtide, ye shall graffe them vpon the Medler tree." 19 This representative formula from Mascall's guidebook hinges on particularity, and necessarily so, for it catalogues stock trees fit for the purpose of grafting a specific scion and producing a specific result. In this 
sense, it differs from the more general instructions Polixenes provides, which feature adjectival markers of an horticultural social order ("gentler," "wildest," "baser," and "nobler" [93-95]) in lieu of individual trees. At first glance, this recipe for mulberries twice deploys a verb ("graffe") that would also seem to afford no evidential support for a terminological linkage between plant grafting and procreation.

The organization of Mascall's guidebook, however, suggests otherwise. At the close of the section on grafting there is appended a "note for all Graffers and Planters." Reminiscent perhaps of a fertility charm, it enjoins gardeners "to saye as foloweth" whenever they plant and graft because the sentiment is "meete and good": "In the name of God the Father, the Sonne and the holy Ghost, Amen. Increase and multiplye, and replenishe the earth." It then advises gardeners to recite the Lord's Prayer and to conclude with this invocation:

Lord God heare my prayer, and let this my desire of thee be hearde. The holy spirite of God which hath created all things for man, and hath giuen them for our comfort, in thy name O Lord we set, plant, \& graffe, desiring that by thy mighty power they maye encrease, and multiplye uppon the earth, in bearing plenty of fruite, to the profite and comfort of all thy faithfull people, thorow Christe or [sic] Lorde. Amen. ${ }^{20}$

Directing gardeners to rehearse variants of "increase and multiply," Mascall's guidebook quotes Old Testament vocabulary of human procreation after the Creation (Genesis 1:28) and for human procreation and animal propagation after the Flood (Genesis 8:17 and Genesis 9:1). ${ }^{21}$ Addressed to the parents of Judeo-Christian humanity and subsequently to the first post-diluvian patriarchal family and pronounced with reference to the pairs of mating animals released from Noah's Ark, the divine phrase "increase and multiply" decrees a future of generational abundance for higher order creatures. Yoking "set, plant \& graffe" to "increase and multiply" in his final "note," Mascall recontextualizes these Old Testament imperatives for generation so that they now pertain to lower order creatures like flowers, plants, and fruit-bearing trees. He thus folds all the agricultural and horticultural prescriptions he enumeratesincluding that recipe for ripening mulberries early or late-retroactively under the rubric "increase and multiply."

Gervase Markham, a prolific writer of early English "how-to" books, likewise aligns grafting with this Biblical idiom for genealogy and generation in The English Husbandman (1613). At the start of a section devoted to the maintenance of trees ("Of the Dressing, Dungging, Proyning, and Preseruing of Trees") Markham inventories those gardening labours he has detailed so far. "Sith after all the labour spent of ingendring by seede, of fortefying and inabling by planting, and of multiplying by grafting," he begins, "it is to little or no purpose if the trees be not maintained and 
preserued." 22 As in Mascall's guidebook, The English Husbandman retrospectively casts a host of prescriptions for grafting as "multiplying," for nowhere else in its pages on grafting does it refer to this mathematically fruitful term. Yet unlike Mascall's guidebook, The English Husbandman splinters "increase and multiply," declining to situate the one verb it retains in a religious context. The Oxford English Dictionary indicates that during the early seventeenth century, when disjoined from "increase," "multiply" in its first sense means to "increase or cause to increase in number, quantity, etc." Among the sub-meanings for this sense, the OED lists to "cause (a family, population, etc.) to increase in numbers by reproduction or procreation" and cites the divine promise Jacob rehearses in the King James translation (1611) of Genesis: "Behold, I wil make thee fruitfull, and multiplie thee, and I will make of thee a multitude of people, and will giue this land to thy seede after thee, for an euerlasting possession" (48:4). ${ }^{23}$ Echoing the assurances God makes after the expulsion from Eden and after the Flood, this Biblical verse contracts the phrase "increase and multiply" as well as its associations into the single verb "multiplie." Less explicitly than in Mascall's guidebook, then, the weight of the Old Testament paradigm "increase and multiply" leaves its imprint on the designation of grafting as "multiplying" in The English Husbandman.

The concentration of genealogical energies in the second term of the Biblical phrase "increase and multipy" tells, of course, only half the story. The verb "increase" means, and is denotatively related to the idea of, "multiply" in sixteenth- and seventeenth-century contexts. ${ }^{24}$ Perhaps more readily than does "multiply," it functions as a mnemonic for the Biblical formula, for it comes first in the verbal sequence. And, importantly for my argument, its nominal form organizes the persuasions the speaker employs from the outset of Shakespeare's procreation sonnets. Consider the opening gambit of Sonnet 1:

\section{From fairest creatures we desire increase, That thereby beauty's rose might never die, But as the riper should by time decease His tender heir might bear his memory [.] (11.1-4)}

Echoing the assured authority ("we") of the instructions for plant grafting that Polixenes rehearses in The Winter's Tale, this quatrain makes the most beautiful ("fairest") young man's "tender heir" synonomous with the noun "increase." In Sonnet 6 the speaker articulates how this heir apparent will continue to "bear" his father's "memory" when he, too, "should by time decease": the young man generates heirs multiplicatively at the ideal rate of "ten for one" in Sonnet 6 (1.8) so that, when "ten of thine [heirs] ten times [has] refigured thee" (1.10), the young man 
remains "living in posterity" many times over (1.12). Although the gender logics of this fantasy of genealogical "increase" would seem to accord with those of Genesis 48:4, where God vows to multiply Jacob into a "multitude of people" without mentioning Jacob's wives Leah or Rachel, Sonnets 1 and 6 also indicate that marriage and a wife's generative body are integral conditions of this fantasy's possibility. If the young man continues "contracted to [his] own bright eyes" (Sonnet 1, 1.5) and declines to "[m]ake sweet some vial" with a seminal deposit before "winter's ragged hand deface[s]" his "summer" (Sonnet 6, 1l.1-3), then this fantasy will turn nightmarish: in procreation, the speaker reports in Sonnet 11, "lives wisdom, beauty, and increase; / Without this, folly, age, and cold decay” (11.5-6). Through Sonnet 15, the only viable option for warding off genealogical disaster available to the young man is procreative marital sex with a (presumably, though not necessarily, equally fair ${ }^{25}$ ) woman. In detailing the terms of this option, the speaker all but chants the mantra "increase and multiply."

Whereas writers of sixteenth- and early seventeenth-century gardening literature co-opt this Biblical paradigm to help conceptualize the act of grafting, the speaker of Shakespeare's procreation sub-sequence enlists arboricultural, agricultural, and horticultural imagery to elaborate a rationale for, and a vocabulary for describing, the option "increase and multiply." In a number of sonnets the speaker draws conceits from the garden and the orchard to figure the act of procreation. Sonnet 3 claims that "some mother" (1.4) would not dare resist the young husbandman's "tillage" (1.6) of her "uneared womb" (1.5). Sonnet 13 links this agricultural image directly to genealogy, for in it the speaker castigates the young man for not employing "husbandry" to "uphold" "so fair a house" (11.9-10). ${ }^{26}$ Like Sonnet 3, Sonnets 5,6 , and 16 hinge on figurations of sexual congress: Sonnets 5 and 6 cast an impregnated uterus as "some vial" or bottle (Sonnet $6,1.3$ ) full of "flow'rs distilled" (Sonnet $5,1.13$ ) for cooking or for their scent, ${ }^{27}$ and Sonnet 16 imagines uteruses fit for impregnation as "maiden gardens" (1.6) and semen / heirs as the young man's "living flowers" (1.7). ${ }^{28}$ Although he does so less frequently, the speaker also engages arboricultural and horticultural conceits to highlight the urgency for procreation. ${ }^{29}$ Sonnet 2, for instance, predicts that the young man will become a "tottered weed" (1.4) unless he sires an heir, and Sonnet 12 invokes a "violet past prime" (1.3) and "lofty trees ... barren of leaves" (1.5) to conjure up a frightening scene of enfeebled sterility.

In Sonnets 1, 11, and 15, the speaker layers the two uses of this garden and orchard imagery, doing so, I suggest, because he engages the word "increase." Sonnet 1, as we have already observed, strongly advises procreative "increase" as a prophylactic 
against the looming effects of ripening (1.3) on "beauty's rose" (1.2). Sonnet 11 similarly insists that impending "age" and "cold decay" (1.6) necessitate the call for such "increase" (1.5). And Sonnet 15 repeats this trajectory, though "increase" switches from a noun to a verb in this poem:

When I perceive that men as plants increase,
Cheerèd and checked ev'n by the selfsame sky,
Vaunt in their youthful sap, at height decrease,
And wear their brave state out of memory[.] (11.5-8)

Echoing the sequence's opening quatrain precisely in rhyme scheme and partially in rhyme words (increase, die, decease, and memory), these lines make explicit the analogy emphasizing the prospect of the young man as a decayed plant in Sonnet 2 ("tottered weed" [4]) and in Sonnet 12 ("violet past prime" [3] and "lofty trees ... barren of leaves" [5]). For as "plants increase" (1.5) and "at height decrease" (1.7), the speaker proposes, so too do "men" (1.5). In this quatrain, the speaker reiterates a melancholy point about the cycle of life he first implied in Sonnet 1's image of "beauty's rose" (1.2) and then more abundantly articulated at the opening of Sonnet 15: "When I consider everything that grows/ Holds in perfection but a little moment" (11.1-2). Importantly, Sonnet 15's rehearsal of this sentiment embeds a punning means for men - and specifically for the young man - to prevent the inevitability of death: they could "increase" in a procreative sense. The tilling of an "uneared womb" (Sonnet 3, 1.5), for instance, would produce "living flowers" (Sonnet 16, 1.7) or heirs, genealogically liberating the young man from the predictable, natural course of the human / plant life cycle.

According to the logic of this quatrain, plants must likewise have the capacity to "increase" in a procreative sense. In light of the prescriptive literature on grafting printed in the sixteenth and early seventeenth centuries, such a statement should not register as eccentric or far-fetched. Indeed, the close of Sonnet 15 records an indebtedness to this literature. There, the speaker announces his intention to work on the young man's behalf against the effects of age and decay- "I engraft you new" (1.14). Because the young man has presumably not heeded (or cannot, or will not, or was never meant to heed) ${ }^{30}$ the call to "increase and multiply," the speaker fashions himself the young man's gardener or husbandman. Taking it upon himself to ensure that the young man's lineage does not fall into ruin, the speaker treats the young man as a plant scion that can be made to "increase and multiply" through an act of grafting. The literary kin of a disguised Polixenes from The Winter's Tale, the speaker sets out to manipulate the young man's genealogical duties: to "engraft" the young man / scion is to "marry" (4.4.92) him and his "youthful sap" (Sonnet 15, 1. 7) to a 
female stock plant (the presumed wife) and thereby "make" her "conceive" (4.4.94) an heir, a "new" iteration (Sonnet 15, 1.14) of "beauty's rose" (Sonnet 1, 1.2). Wittily engaging those verbs common to the discourses of grafting and of Old Testament procreation, the speaker promises to yield for the young man that which he has not produced (or cannot, or will not, or was never meant to produce) himself. His grafting codes as procreative "increase," a genealogical act that makes the beautiful young man "new made" (Sonnet 2, 1.13).

\section{Growing Flowers of Poetry}

Although the immediate matter of dispute in the Bohemian countryside of The Winter's Tale is grafting, members of Shakespeare's audience might have recognized that the terms of the debate convened there apply equally well to Renaissance commentary about poetry. For versifying, like grafting, afforded writers an occasion to meditate on the relation between art and nature. In The Defence of Poesy (c. 1581), for instance, Philip Sidney argues for the preeminence of the "art" of poetry over its rival fields of knowledge - history, mathematics, medicine, natural philosophy, among others-because, unlike these arts, poetry does not restrict its "principal object" of investigation to the "works of nature." The poet's art, as Sidney articulates it, is sui generis: "[o]nly the poet, disdaining to be tied to any such subjection, lifted up with the vigour of his own invention, doth grow in effect another nature, in making things either better than nature bringeth forth, or, quite new, forms such as were never in nature, as the Heroes, Demigods, Cyclops, Chimeras, Furies, and such like." The poet, Sidney continues, "goeth hand in hand with nature, not enclosed within the narrow warrant of her gifts, but freely ranging only within the zodiac of his own wit." ${ }^{11}$ Because he is not "tied" to the study of nature's opera, Sidney's poet is, at worst, nature's equal ("hand in hand"), and, at best, her improver ("better") and preternatural competitor ("quite new" / "never in nature").32 In the Bohemian countryside, we recall, such strong claims for the powers of art over nature worry Perdita: she banishes grafted carnations from her garden plot and would likely have little patience for Sidney's poet. Indeed, her dismissal of grafting as "an art which ... shares/ With great creating nature” (4.4.87-88, emphasis added) closely echoes Sidney's figuration of the poet as nature's partner.

Grafting and poetry-making are, of course, not the only Renaissance arts which provoked disputes over, and anxiety about, the category "nature." We might think here of discussions and treatises about humanist education, women's cosmetics or a courtier's machinations, for instance. ${ }^{33}$ Yet we would do well to persist in coupling 
the arts of grafting and of poetry-making, for each art promises to generate flowers. Sixteenth- and seventeenth-century prescriptive literature, as we have observed, conscripts the Biblical paradigm "increase and multiply" to conceptualize the grafting of flowers and of orchard trees. For Sidney, the poet (from the Greek poietes: "maker") likewise engages in an act of generation. ${ }^{34}$ He refines nature's imperfect "things" and originates "forms" like demigods and monsters when, "with the vigour of his own invention," he "doth grow in effect another nature" (emphasis added). Earlier in The Defence, Sidney tellingly designates as the "flowers of poetry" those “mere tales, as Gyges' ring and others” which Plato, the supposed adversary of poetry, narrates. ${ }^{35}$ In drafting Plato into the company of poets, Sidney casts the marvelous story from the Republic of Gyges' invisible ring as a poetic flower, aligning "flowers" with the preternatural "forms" that the poet makes. An allusion to the rhetorical figures or "flowers" of classical oratory, the phrase "flowers of poetry" also accords with Sidney's promotion of art over nature, for it grammatically enfolds a class of natural things ("flowers") under the rubric of art ("of poetry"). Sidney's poet, I am suggesting, makes "another nature" as well as "forms such as were never in nature" by growing "flowers of poetry" whenever he likes under "the zodiac of his own wit." And The Defence implictly figures such growing as grafting, for Sidney insists that the poet can do exactly what Gervase Markham, Leonard Mascall, and even The Winter's Tale's Polixenes maintain that the grafter does-alter, change, make, conceive, devise, and improve upon the nature of flowers.

In his guidebook A New Orchard and Garden (1618) William Lawson helps to elaborate the correlation between grafting and the writing of poetry implied in Sidney's Defence. At the outset of a section entitled "Of Grafting," Lawson designates all the prescriptions for grafting that he logs as forms of writing when he glosses this heading as "Of grauing or caruing" in the margin. ${ }^{36}$ Both of these terms could signal modes of inscription: Donne reports that he "grav' $d$ " his name on a glass in "A Valediction of my name, in the window" (1.4) and As You Like It's Orlando expresses a desire to "carve on every tree" poems celebrating Rosalind (3.2.9).37 Orlando's tree carving could serve as a literary analogue for the most astonishing wooduct image of grafting I have encountered in Renaissance guidebooks for gardening .

In the first illustration (ill. 1) which illustrates directions for a technique Gervase Markham calls "Grafting with the Leafe" in The English Husbandman, depicts a number of cuts incised into tree bark that is remarkable in its resemblance to the letter "H." In the instructions which this image accompanies Markham advises gardeners that "a very sharpe knife" will produce the desired effect. ${ }^{38}$ We get a sense of the selection of sharp-edged implements at the disposal of Renaissance garden- 


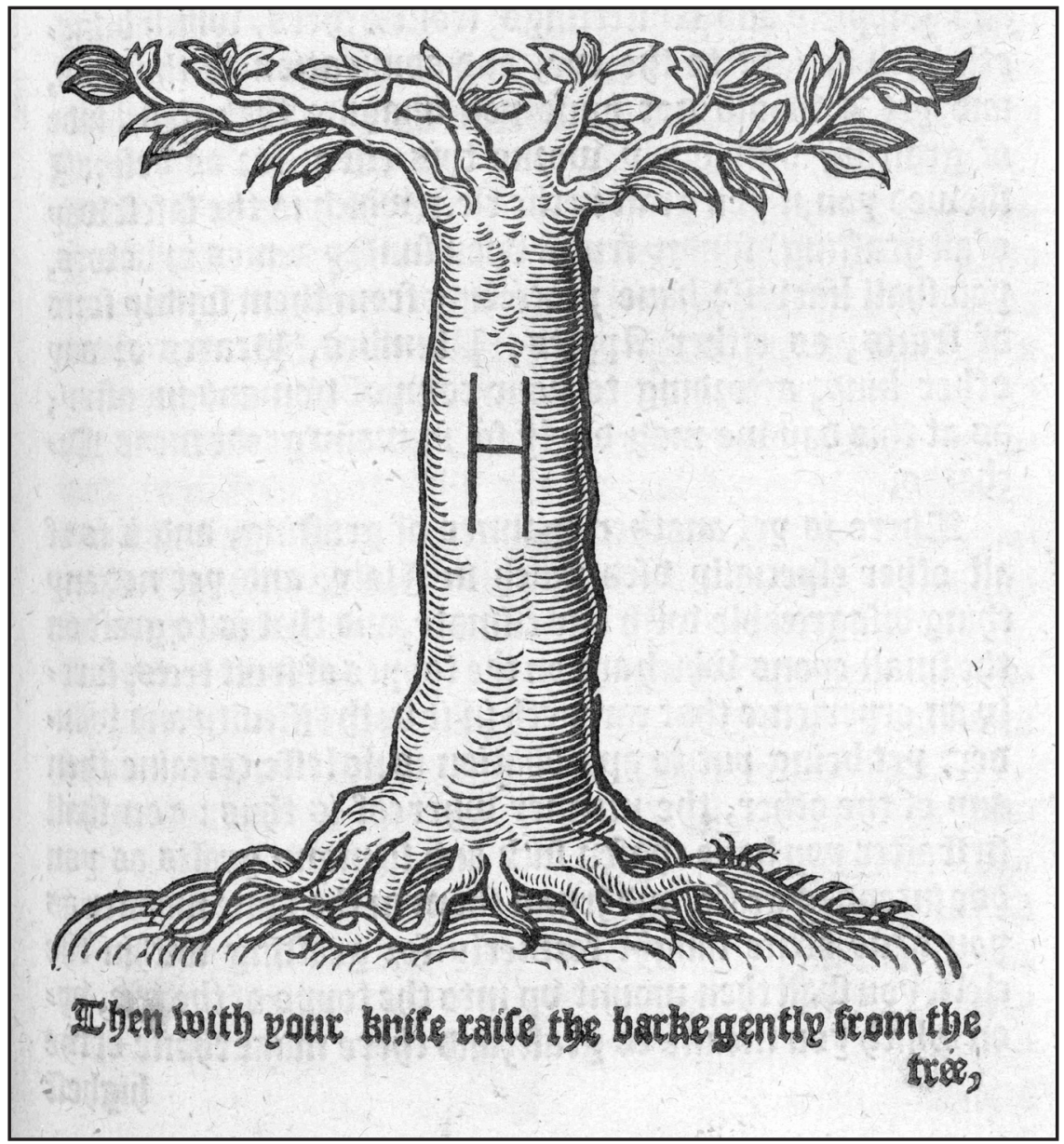

Illustration 1: Markham, The English Husbandman, p. 55 (with permission of the Huntington Library).

ers from a woodcut included in Leonard Mascall's A Booke of the Arte and maner, howe to plant and graffe all sortes of trees. Of especial interest in the next illustation (ill. 2) is the "graffing knyfe," which is located at the lower border, for Lawson's and Markham's grafters likely pluck a similar tool from "their girdel” when they carve and grave.

A readied knife was also a vital implement for the humanist writer. In a study of Renaissance handwriting treatises, Jonathan Goldberg adduces a range of evidence supporting the claim that, at the sixteenth-century humanist desk, "the knife is the 


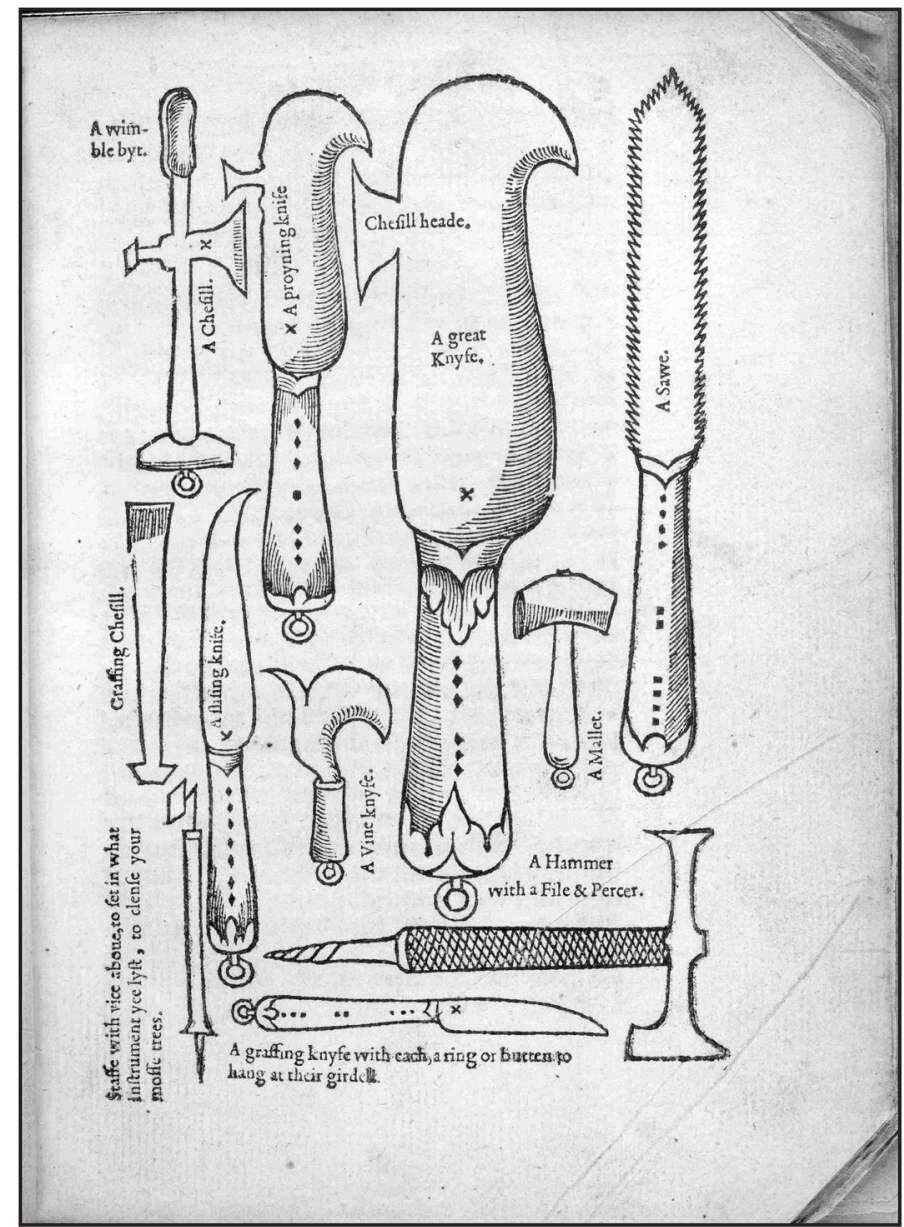

Illustration 2: Mascall, A Booke of the Arte and maner, howe to plant and graffe all sortes of trees ..., prefatory matter (with the permission of the Huntington Library).

support of writing." 39 For the "pen-knife," as verse prefacing John De Beau Chesne and John Baildon's A Booke Containing Divers Sortes of Handes (1570; 1602) indicates, was a "stay in [the] lefthand" of premodern clerks, letter-writers, and secretaries. ${ }^{40}$ Since the Middle Ages, scribes used a penknife to even out the page, to keep their place in the text from which they copied, to scrape away a mistake on the page, and, perhaps most importantly, to prepare the tip of a quill. ${ }^{41}$ Sixteenth- and seventeenthcentury writers of guidebooks about gardening specify this particular type of knife as appropriate for grafting. Gervase Markham, for instance, recommends that scions be "trimmed" with a "sharp knife, made in the proportion of a great pen-knife."42 
Leonard Mascall also advises gardeners to carry "a sharpe penknife, or other sharpe poynted knife." He instructs them not only to shave the ends of scions with one but also to cut directly into the tree bark with it: "thrust it down," he enjoins, "betwixt the barke and the stocke, so long as the incision of your graffes be, then put your graffes softly downe therein to the hard joynt, and see that it doe fit close upon the stocke heade."43 A material support for the arts of grafting and of writing, the penknife sutures acts from seemingly disparate domains: it could pare scion ends just as easily as quill tips. Incising into tree bark a series of cuts that share their form with an alphabetical letter, it could also operate as if it were the grafter's pen.

When the speaker of Shakespeare's Sonnet 15 announces that he will "engraft" the young man "new" (1.14), he would wield, we infer from this prescriptive literature, a penknife or some sharp blade. ${ }^{44}$ At the close of this poem he also declares "war with time for love of you" (1.13), suggesting that his strategy for battle is grafting and his artillery the gardener's tools. In Sonnet 16, however, the speaker instead casts a "pupil pen" (1.10) as his weapon of choice. The pen faces off against "time's pencil" (1.10) in Sonnet 16, an implement often glossed as a painter's brush in commentary but which, as early as the late sixteenth century, also denoted a writing instrument that anticipates the modern mechanical pencil.45 Indeed, Sonnet 19's elaboration of the damage the allegorical figure Time could inflict belongs to the art of writing, not painting: he could "carve" (1.9) and "draw ... lines" of age (1.10) on the young man's "fair brow" (1.9) with an "antique pen" (1.10). Here, Time deploys the same weapon as does the speaker in Sonnet 16, though his proves more well-worn ("antique") than his opponent's ("pupil"). A capacity for carving presses the pen/ cil back into the circuit of metalware, for it requires a sturdy edge or a sharp point to produce depth. A quill pen may lack these qualities, but the kind of tool Time brandishes in Sonnet 12-a "scythe" (1.13) — does not. A symbol associated with the tradition of memento mori, and thus an apt emblem for provoking the sense of dynastic urgency we have observed suffusing the procreation sub-sequence, the scythe is, more literally, a sharp-edged agricultural implement. As such, it is kin to the penknife, the multi-functional object needed for grafting in Sonnet 15 and for the fashioning of quill pens in Sonnets 16 and 19. Although none of these poems in the sub-sequence mentions a penknife, the scythe, I argue, conjures one, reminding us that a blade makes possible the arts of grafting and of writing. ${ }^{46}$ Returning later in the Sonnets to the agon described at the close of Sonnet 15, the speaker more explicitly aligns the scythe with other sharp implements when he extols the durance of his "black lines" over the "lines and wrinkles" of "confounding age's cruel knife" (Sonnet 63, 11.4, 10, 13). 
The speaker's strategy for war in Sonnet 15, of course, predicts his employment of a "pupil pen" in Sonnet 16 (1.10), for "engraft" puns on graphein (Greek: "to write"). Because the penknife organizes a material relation between grafting and writing, we would do well not to regard the speaker's use of "engraft" as simply an instance of proleptic wordplay and to presume that its meaning in gardening discourse evaporates as soon as the speaker invokes it to figure his writing. The verb "engraft" works, in part, to signal that the speaker continues to focus on the matter of procreation in those poems about writing after Sonnet 15. In Sonnet 16, for example, he dubs his writing "barren rhyme" (1.4). The final couplet of the next poem, however, quickly cancels out this self-deprecating estimation: "But were some child of yours alive that time,/ You should live twice in it and in my rhyme" (Sonnet 17, 11.13-14). Conjoining the "child" (1.13) that procreation would yield with his "verse" (1.1), the speaker equates heirs and poems. He casts both as receptacles ("in") where the young man could conceivably "live" (1.14) and might even imagine the possibility that "rhyme" (1.14), like "some child" (1.13), has a capacity for being "alive" (1.14). At the close of Sonnet 18, the speaker ratifies this possibility, making the young man's dynastic continuance in verse a condition of poetry's durance: "So long lives this, and this gives life to thee" (1.14). The antecedent of the reiterated "this" is the speaker's "eternal lines," which prove both vital and vitalizing, for, in them, the speaker avers, the young man "grow'st" "to time" (1.12). In Sonnet 19 the speaker advances this gambit one degree further. He claims there that his poetry exempts the young man from the inexorability of death: "My love shall in my verse ever live young" (1.14).

Since the speaker designates his writing as versifying in Sonnets 16, 17, 18, and 19, his use of "engraft" also works to highlight that a poet, like a grafter, manipulates the generation of flowers. Vivified and dynastically invigorating, flowers of poetry in these sonnets might best be glossed with the speaker's own phrase from Sonnet 16 for describing the young man's potential descendants, "living flowers" (1.7). ${ }^{47}$ Embodied in these poetic flowers, the speaker boasts in Sonnet 18, the young man "to time grow[s]" (1.12). Thus made to live perpetually and, in Sonnet 19, to live forever "young" (1.14) in flowers of poetry, the young man becomes a marvelous floral artifact. As he did in Sonnet 15, he still "grows" (1.1) but he now no longer proves subject to a natural life cycle culminating in his own death, for he has been captured in the "eternal lines" (Sonnet 18,1.12) of lineage. In articulating this poetic model of preternatural generation and genealogy, the speaker, as Jonathan Goldberg observes, creates a "text that duplicates the world and outsrips it in its generativity," tellingly echoing and surpassing the presentation in earlier sonnets of the end-run around 
death that procreative sex had promised to afford..$^{8}$ The speaker's elaboration of this poetic model of endless generation engages, I think, intertextually with the art / nature debate in Sidney's Defence, for there Sidney maintains that the poet "doth grow in effect another nature." At the close of the procreation sub-sequence the speaker has professed himself to be just such a poet. But before he does so he has designated himself a grafter.

\section{Seedless Generation}

In his reading of Sonnet 15 , Bruce Smith argues that the poet effectively keeps discrete two contexts for comprehending the verb "engraft," for the "poet creates" while the "friend procreates." Even though this essay has outlined, to a large extent, these contexts independently, they remain coincident in my reading of Sonnet 15. This verb, I argue, functions as a hinge linking these contexts, as if vehicle and tenor in this poem have themselves been grafted or fused together. "Engraft" simultaneously aligns the poem with the speaker's preceding appeals for the young man to "increase and multiply" and marks itself as the earliest instance of the speaker's self-presentation as an agent ("I engraft you new") who claims that he can generate a lineage for the young man through poetry. This reading of "engraft" might help to specify more abundantly than has been done before how the speaker, in Valerie Traub's apt formulation, "appropriate[s] procreation to authorize male bonds," sociability, and desire. ${ }^{49}$ In its capacity as a rhetorical joint, the speaker's "engraft" thus establishes continuity between hetero- and homoerotic models of generation, highlighting the non-distinction between what we would typically call "heterosexuality" and "homosexuality," suggesting (once again) the anachronism of these categories in Shakespeare's England.

Unlike much important scholarship on the sub-sequence and on Renaissance versifying more generally, I have deliberately not referred to procreation as "reproduction" 50 or to poetry-making as "male parthenogenesis" ${ }^{11}$ in my elaboration of the hinge logic of "engraft." I do so, in part, because these nomenclatures prove anachronistic. "Reproduction" and "parthenogenesis" not only lack widespread circulation in sixteenth- and seventeenth-century English, but the latter term actually denotes something other than what scholars take it to mean. First used in the nineteenth century, "parthenogenesis" etymologically signals the development of an unfertilized or virgin (Greek: parthenos) ovum..$^{52}$ Eve Keller's recent study of Renaissance treatises about midwifery and obstetrics points to the unsuitability of employing "reproduction" in late sixteenth- and early seventeenth-century English 
contexts. The word "became current," she notes, "only after the physiological processes from conception through birth came to be understood within the context of mechanism." 53 Prior to the articulation of mechanistic embryology and its semantics of reproduction in mid-seventeenth-century England, however, procreation was indeed conceived as analogous to, and consonant with, mechanical forms, which phenomenon Margreta de Grazia has dubbed the "mechanics of the imprint" signets, coins, woodblocks, stamps, and printing presses. ${ }^{54}$ Douglas A. Brooks has speculated that "the conceptual, rhetorical, and metaphorical links between procreation and authorship, between reproduction and publication" forged by these earlier mechanics "may well be the very foundation of history itself." 55

But in practical terms, plant grafting proves an altogether different model of generation, for although it has affinities with the graphic technology of "engraving," its imprinting, I argue, is aligned uneasily in grafting guidebooks with a lexicon of human procreation and parenting. In the same gardening manuals that employ the rhetoric of "increase and multiply" to comprehend the processes of plant grafting as sexualized, there is also an insistence, in the formulation of manual writer Gervase Markham, that plant grafting is not an "ingendring by seede." A third party-the gardener-poet - must, after all, join the saps of a scion and a stock plant to (pro)create new, improved, or additional flowers and fruit. The "graft," then, just may prove a helpful category for telling a queerer version of generational and genealogical history, both sexual and textual. This history's foundation is a seedless generation, a genealogy unmoored from an act of conjugal procreation.

\section{Notes}

I would like to thank Patricia Badir, Stephen Guy-Bray, Deanna Kreisel, Christina Lupton, Scott MacKenzie, Gregory Mackie, Robert Rouse, Will Stockton, and Sandra Tomc, as well as the two anonymous readers for the journal, for the wonderful suggestions and helpful comments.

1. All references to the sonnet sequence are from Shakespeare's Sonnets, ed. Stephen Booth (New Haven, cт: Yale University Press, 1977).

2. Bruce R. Smith, Homosexual Desire in Shakespeare's England: A Cultural Poetics (Chicago: The University of Chicago Press, 1991), pp. 247-48.

3. Smith, p. 248.

4. Smith, pp. $15,19$.

5. On the homoerotic deployment of classical myths and texts, see, among others, Smith, and Stephen Guy-Bray, Homoerotic Space: The Poetics of Loss in Renaissance Literature (Toronto: University of Toronto Press, 2002). On affectionate gestures in male-male correspondence, see Jeffrey Masten, “Toward a Queer Address: The Taste 
of Letters and Early Modern Friendship,” A Journal of Lesbian and Gay Studies 10.3 (2004), pp. 367-84.

6. Important studies of "lesbian" desire and female homoeroticism include Theodora A. Jankowski, “ ... in the Lesbian Void: Woman-Woman Eroticism in Shakespeare's Plays," A Feminist Companion to Shakespeare, ed. Dympna Callaghan (Malden, MA: Blackwell, 2000), pp. 299-319; Kathryn Schwarz, Tough Love: Amazon Encounters in the English Renaissance (Durham, NC: Duke University Press, 2000); Laurie Shannon, Sovereign Amity: Figures of Friendship in Shakespearean Contexts (Chicago: The University of Chicago Press, 2002); and Valerie Traub, The Renaissance of Lesbianism in Early Modern England (Cambridge: Cambridge University Press, 2002).

7. Crucial, recent forays into the project of re-thinking Renaissance heterosexuality include Jonathan Goldberg, Desiring Women Writing: English Renaissance Examples (Stanford, CA: Stanford University Press, 1997), pp. 91-113; Celia R. Daileader, "Back Door Sex: Renaissance Gynosodomy, Aretino, and the Exotic," English Literary History 69 (2002), pp. 303-34; Maureen Quilligan, Incest and Agency in Elizabeth's England (Philadelphia: University of Pennsylvania Press, 2005); Daniel Juan Gil, Before Intimacy: Asocial Sexuality in Early Modern England (Minneapolis and London: University of Minnesota Press, 2006); and Stephen Guy-Bray, "Shakespeare and the Invention of the Heterosexual," Early Modern Literary Studies 13.2 (2007), pp. 1-28.

8. Rebecca Ann Bach, Shakespeare and Renaissance Literature Before Heterosexuality (New York: Palgrave Macmillan, 2007).

9. Laurie Shannon, "Nature's Bias: Renaissance Homonormativity and Elizabethan Comic Likeness," Modern Philology 98.2 (2000), pp. 183-210.

10. For a lovely account of the "nonsexual production of plants by seed" in later seventeenth-century thought, see Marjorie Swann, “Procreate Like Trees': Generation and Society in Thomas Browne's Religio Medici," in Engaging with Nature: Essays on the Natural World in Medieval and Early Modern Europe, ed. Barbara A. Hanawalt and Lisa J. Kiser (Notre Dame: University of Notre Dame Press, 2008), pp. 137-54, esp. p. 145 .

11. On the preternaturalness of grafting, see Shannon, Sovereign Amity, pp. 216-17. On the "inhuman" sexuality glimpsed in Shakespeare's Sonnets, see Jonathan Goldberg, "The Anus in Coriolanus," Historicism, Psychoanalysis, and Early Modern Culture, ed. Carla Mazzio and Douglas Trevor (London and New York: Routledge, 200o), p. 269.

12. All references to Shakespeare's plays are from The Norton Shakespeare, gen. ed. Stephen Greenblatt (New York: W.W. Norton, 1997).

13. Gabriel Egan interestingly suggests that Perdita and Polixenes are at cross-purposes in this scene, and so she does not so much capitulate to Polixenes as resign to his "miscomprehension" of her misgivings about the artificial-seeming produce of crosspollination. That these two interlocutors are at cross-purposes might explain why, when Perdita brings up floral grafting (cross-pollination, for Egan), Polixenes then discusses the stocks and scions of orchard grafting. See Green Shakespeare: From Ecopolitics to Ecocriticism (London: Routledge, 2006), pp. 129-30. 
14. Rebecca Bushnell, Green Desire: Imagining Early Modern English Gardens (Ithaca: Cornell University Press, 2003), pp. 136-40; 149-50.

15. On the dynamics of early modern cultural reproduction, demography, and governmentality, see David Glimp, Increase and Multiply: Governing Cultural Reproduction in Early Modern England (Minneapolis: University of Minnesota Press, 2003).

16. On the sixteenth century as an episteme of resemblance, see Michel Foucault, The Order of Things: An Archeology of the Human Sciences (New York: Random House, 1970), pp. 17-45. When, in Foucault's terms, resemblance no longer had epistemological purchase, plant sexuality and the classification of plant anatomy became renewed foci of scientific investigation in the eighteenth century. For a more detailed history of botanical thought in England through the early eighteenth century, when the logics of plant hybridization were "discovered," see Bushnell, Green Desire, pp. 1326o. It seems, though, that resemblance continued to hold sway even in Enlightenment plant taxonomies. Elizabeth Hackendorn Cook notes that the botanical writings of Linnaeus anthropomorphized plant sexuality, imposing a model of "human heterosexual monogamy” upon it. See Cook's intriguing essay, “Perfect' Flowers, Monstrous Women: Eighteenth-Century Botany and the Modern Gendered Subject," "Defects": Engendering the Modern Body, ed. Helen Deutsch and Felicity Nussbaum (Ann Arbor: The University of Michigan Press, 200o), pp. 252-79, esp. p. 259.

17. For a thorough history of grafting manuals in the English book trade and of how these manuals comprehended the processes of grafting, see Bushnell, Green Desire, pp. 140-60. For seventeenth-century treatments of grafting, see also Claire Preston, "Of Cyder and Sallets: The Hortulan Saints and The Garden of Cyrus," Literature Compass 3.4 (2006), pp. 867-83.

18. On the relation between secrets books and grafting recipes, see Bushnell, Green Desire, pp. 140-48. On the genre of secrets books more generally, see William Eamon, Science and the Secrets of Nature: Books of Secrets in Medieval and Early Modern Culture (Princeton: Princeton University Press, 1994).

19. Leonard Mascall, A Booke of the Arte and maner, howe to plant and graffe all sortes of trees ... (London, 1572), p. 57.

20. Mascall, p. 61, though the guidebook is mispaginated at this point.

21. Although the King James Bible consistently invokes the phrase "be fruitfull, and multiply," the translating of the Vulgate Bible's imperatives "Crescite et multiplicamini" as "increase and multiply" was indeed current in Elizabethan England. In his description of the Garden of Adonis in Book 3, Canto 6 of The Faerie Queene, for instance, Spenser reports that:

Ne needs there Gardiner to set, or sow,

To plant or prune: for of their owne accord

All things, as they created were, doe grow,

And yet remember well the mightie word,

Which first was spoken by th' Almightie lord, 


\section{That bad them to increase and multiply[.] (Stanza 34)}

I have consulted The Faerie Queene, ed. Thomas P. Roche, Jr. (London: Penguin Books, 1987) and Scott E. Goins, A Vulgate Old Testament Reader (Piscataway, NJ: Gorgias Press, 2005), p. 5 .

22. Gervase Markham, The English Husbandman (London, 1613), p. 62.

23. All references are from the Oxford English Dictionary Online, <www.dictionary.oed >. I accessed this site on June 13, 2007.

24. See the first two witnesses listed for the verb "increase" in the online OED. I accessed this site on June 13, 2007.

25. The speaker urges the young man to "[m] ake sweet some vial" (1.3), and we might hear, as Stephen Booth does in his commentary on this line, in that "vial" a pun on "vile." Although I do not foreground matters of elitism, misogyny, and racism in this essay, the possibility of "vile" alerts us to their importance in the genealogical discourse of the procreation sonnets; the relations among social rank, race, and grafting in these poems indeed merit further investigation. For an account of social rank as a crucial factor in interpreting sonnets addressed to the beautiful young man and to the socalled Dark Lady, see Margreta de Grazia, “The Scandal of Shakespeare's Sonnets.” In "Sex Without Issue: Sodomy, Reproduction, and Signification in Shakespeare's Sonnets," Valerie Traub scrupulously examines the relation between misogyny and non-procreative, and therefore historically sodomitical, sex in the Dark Lady subsequence. Both de Grazia's and Traub's essays are collected in Shakespeare's Sonnets: Critical Essays, ed. James Schiffer (New York: Garland Publishing: 1999), pp. 89-112 and pp. 431-52, respectively. For a hallmark discussion of the structures of homosociality and misogyny in the Sonnets, see Eve Kosofsky Sedgwick, Between Men: English Literature and Male Homosocial Desire (New York: Columbia University Press, 1985).

26. For an important reading that emphasizes the failure of husbandry in the Sonnets, see Thomas M. Greene, The Vulnerable Text: Essays on Renaissance Literature (New York: Columbia University Press, 1986), pp. 175-93, esp. pp. 176-77.

27. There is scholarly disagreement about the discourse of perfumery in Sonnets 5 and 6. In "Shakespeare's Perfume," Richard Halpern remarks that the "walls of glass" (1.10) in Sonnet 5 suggest a "conspicuously sterile and inorganic image for the womb," arguing instead that the sonnet is a "tiny treatise on poetic sublimation": "Shakespeare's image of the perfume bottle takes the commonplace but mysterious process whereby the father's sexual substance produces a baby, and puts in its place the even more mysterious process whereby the young man's sexual substance-his semen-is distilled into poetry." For Halpern, the aestheticizing of semen accords more with the improper use of ejaculate in sodomy than it does with its fruitful possibility in procreation. In response to Halpern's essay, Jeffrey Masten has pointed out that a "generally Aristotelian, roughly parthenogenic" "model of reproduction" would make Halpern's reading of the perfume bottle less likely. I am sympathetic to Masten's 
historicizing project in "Gee, Your Heir Smells Terrific: Response to 'Shakespeare's Perfume.” I think it is possible to regard the procreation sonnets as accommodating, indeed intermixing, Biblical and other classical models of generation; as I note in the conclusion of this essay, though, I would also quibble with Masten's use of "reproduction" and "roughly parthenogenic" to describe generation in the sub-sequence. I accessed both essays at <http://emc.eserver.org/1-2/> on May 6, 2007.

28. By casting "living flowers" as the young man's semen I am suggesting that "flowers" may not have referred only to female menses in Shakespeare's England. See Louis Adrian Montrose, "'Shaping Fantasies': Figurations of Gender and Power in Elizabethan Culture,” Representations 2 (1983), n. 44, pp. 92-93. Nonetheless, we might also want to regard "living flowers" in the context of Renaissance anatomical illustration, particularly those illustrations figuring the female's organs of generation as a blooming flower and the fetus as the bud of this bloom. On the tradition of the "flowering foetus" in anatomical illustration, see Jonathan Sawday, The Body Emblazoned: Dissection and the Human Body in Renaissance Culture (London and New York: Routledge, 1995), p. 216 and Karen Newman, Fetal Positions: Individualism, Science, Visuality (Stanford, CA: Stanford University Press, 1996), pp. 82-83.

29. For a discussion of the acceleration of time in the procreation sub-sequence, particularly of seasonal rhythms, see Dympna Callaghan, "Confounded by Winter: Speeding Time in Shakespeare's Sonnets," A Companion to Shakespeare's Sonnets, ed. Michael Schoenfeldt (Malden, MA: Blackwell, 2007), pp. 104-18.

30. For an insightful account of the young man's resistance to the procreative imperative upon which the speaker harps, see Garrett A. Sullivan, Jr., "Voicing the Young Man: Memory, Forgetting, and Subjectivity in the Procreation Sonnets," A Companion to Shakespeare's Sonnets, pp. 331-42.

31. Philip Sidney, The Defence of Poesy in Sir Philip Sidney: A Critical Edition of the Major Works, ed. Katherine Duncan-Jones (Oxford: Oxford University Press, 1989), pp. $215-16$.

32. For a discussion of the dynamics of gender subordination in this passage and, more generally, in Renaissance treatises on poetry, see Frances E. Dolan, "Taking the Pencil out of God's Hand: Art, Nature, and the Face-Painting Debate in Early Modern England," Publications of the Modern Language Association of America 108.2 (1993), pp. 224-39, esp. pp. 225-27. On the misanthropy, somatophobia, and especially misogyny that "accompanies the power of art to produce a second and better nature," see Harry Berger, Jr., "Second-World Prosthetics: Supplying Deficiencies of Nature in Renaissance Italy," Early Modern Visual Culture: Representation, Race, and Empire In Renaissance England, ed. Peter Erickson and Clark Hulse (Philadelphia: University of Pennsylvania Press, 2000), pp. 98-47, esp. p. 112.

33. On the art / nature debate in Renaissance cosmetics, see Dolan. On the art / nature debate in humanist education, see Rebecca Bushnell, A Culture of Teaching: Early Modern Humanism in Theory and Practice (Ithaca: Cornell University Press, 1996). For more on the relation between Renaissance machines and attitudes about the nat- 
uralness of courtly artifice, see Jessica Wolfe, Humanism, Machinery, and Renaissance Literature (Cambridge: Cambridge University Press, 2004).

34. Although he does not discuss this moment in The Defence, Glimp aptly describes Sidney as engaging in "poetic genesis." See Increase and Multiply, p. 40.

35. Sidney, pp. 213-14.

36. William Lawson, A New Orchard and Garden (London, 1618), p. 27. Robert Rouse has suggested to me that the historical relations between the consonants " $\mathrm{f}$ " and " $\mathrm{v}$ " and between "v" and "u" may render Lawson's "grauing" as an equivalent to "graf[f] ing." The $O E D$ records one late-fourteenth-century witness of "graffed" that denotes "to dig," explicitly marking this verb as a variant of "to grave." I accessed this site on September 1, 2007.

37. I consulted John Donne's Complete English Poems, ed. C.A. Patrides (London: J.M. Dent, 1985).

38. Markham, p. 55. An " $\mathrm{H}$ " also appears as a woodcut image accompanying a procedure dubbed "Graffing in the Scutchion" in William Lawson's gardening guidebook, though it is not presented as having been incised into tree bark there. See A New Orchard and Garden, p. 32. Were we to regard the grafter's " $H$ " as akin to an initial (for "husbandman"?), we might also consider it a domestic version of the staple moment in European conquest narratives where a mark emblazoned onto bark signals domination over the land. On this practice, see Stephen Greenblatt, Marvelous Possessions: The Wonder of the New World (Chicago: The University of Chicago Press, 1991), p. 56 and Philip D. Morgan, "Encounters between British and 'indigenous' peoples, c. 1550-1800," in Empire and Others: British Encounters with Indigenous Peoples, 1500180o, ed. Martin Daunton and Rick Halpern (Philadelphia: University of Pennsylvania Press, 1999), p. 51.

39. Jonathan Goldberg, Writing Matter: From the Hands of the English Renaissance (Stanford, CA: Stanford University Press, 1990), p. 78.

40. This snippet of prefatory verse is quoted in Goldberg, Writing Matter, p. 78.

41. On the use of penknives in medieval manuscript culture, see Christopher De Hamel, Medieval Craftsmen: Scribes and Illuminators (Toronto: University of Toronto Press, 1992), p. 29.

42. Markham, pp. 48-49.

43. Mascall, p. 33 .

44. For a brief discussion of knives and pens in Shakespeare's Sonnets, see Olga L. Valbuena, “'The dyer's hand': The Reproduction of Coercion and Blot in Shakespeare's Sonnets" in Shakespeare's Sonnets: Critical Essays, pp. 325-45, esp. pp. 332-33.

45. See definition 2(a) for "pencil" in the online OED. I accessed this site on July 8, 2007.

46. Time's scythe also conjures the absent knife looming behind the image of the young man as "carved" (1.13) by "nature for her seal" (1.13) in Sonnet 11. These implementsa signet seal and a hand-held blade for carving a seal—cast this poem's final line ("Thou shouldst print more, not let that copy die"), which is traditionally interpreted 
as a reference to the mechanical reproductions of the printing press, as an allusion to a scene of letter-writing at the humanist desk.

47. See also Joel Fineman, Shakespeare's Perjured Eye: The Invention of Poetic Subjectivity in The Sonnets (Berkeley and Los Angeles: University of California Press, 1986), p. 206.

48. Jonathan Goldberg, Voice Terminal Echo: Postmodernism and English Renaissance Texts (New York: Methuen, 1986), p. 131.

49. Valerie Traub, “Sex Without Issue," p. 440.

50. For criticism on the Sonnets employing "procreation" and "reproduction" synonymously, I cite an example which has been invaluable to my thinking about these poems: Traub, "Sex Without Issue."

51. For a sustained characterization of Sidney's poetics as "parthenogenesis," see Glimp, pp. 37-62.

52. The online OED's first witness for "parthenogenesis" dates from 1849. I accessed this site on July $15,2007$.

53. See Eve Keller, Generating Bodies and Gendered Selves: The Rhetoric of Reproduction in Early Modern England (Seattle and London: University of Washington Press, 2007), n. 1, p. 191. Keller further notes that these texts routinely deploy the term "generation." According to the online $O E D$, the earliest witness of the verb "reproduce" dates from Randle Cotgrave's 1611 French-English dictionary. The online OED does not record its use again until the mid-seventeenth century; "reproduction" begins circulating in written discourse around this time as well. I accessed this site on July 15, 2007. The first witness for "reproduire" in v. 8 of Le Robert Dictionnaire De La Langue Française dates from 1539; the next citation for this verb dates from 1690. The noun "reproduction" likewise dates from 1690, and "se reproduire" is recorded in 1712. Intriguingly, Mary Thomas Crane remarks that, although "pregnancy" denoted "with child" as early as 1545 in an English obstetrical treatise, "the reproductive sense of the word did not enter common usage until the mid-seventeenth century." Before then it "referr[ed] primarily to a mental condition"- to the pregnant mind. See Shakespeare's Brain: Reading with Cognitive Theory (Princeton, NJ: Princeton University Press, 2001), p. 159. Our commonsense understanding of "reproduction" and "pregnancy" owes a profound debt, this philological evidence intimates, to the conceptual conspiring of mechanistic philosophy and, as my next endnote elaborates, the printing press.

In “The Promises of Monsters," Donna Haraway proposes, with some flair, that we would do well to "displace the terminology of reproduction with that of generation. Very rarely does anything really get reproduced; what's going on is much more polymorphous than that. Certainly people don't reproduce, unless they get themselves cloned, which will always be very expensive and risky, not to mention boring." I cite this essay from The Haraway Reader (New York and London: Routledge, 2004), pp. 63-124, esp. p. 69. My suggestion is that such a project would itself do well to historicize "reproduction" in order to make the case for its misapplication in pre-mod- 
ern and post-human contexts. For more on this point, see Stephen Orgel, "Marginal Maternity: Reading Lady Anne Clifford's A Mirror for Magistrates," in Printing and Parenting in Early Modern England, ed. Douglas A. Brooks (Burlington, vT: Ashgate, 2005), pp. 267-89, esp. pp. 288-89.

54. For a scrupulous account of this habit of thought, see Margreta de Grazia, "Imprints: Shakespeare, Gutenberg, and Descartes," in Printing and Parenting, pp. 29-58, esp. p. 42. For pre-lithographic, pre-photographic, and pre-filmic forms of mechanized reproduction, see also Walter Benjamin, "The Work of Art in the Age of Mechanical Reproduction” Illuminations, ed. Hannah Arendt (New York: Schocken Books, 1969), pp. 218-19.

55. Brooks, p. 2. 